\title{
Response to comment of Dr Kamal Chaouachi on "Shisha Smoking, Nickel and Chromium Levels in Tunisia"
}

\author{
Rim Khlifi
}

Received: 11 June 2013 / Accepted: 10 July 2013 / Published online: 23 August 2013

(C) Springer-Verlag Berlin Heidelberg 2013

\section{Dear Editor,}

We have been informed of Dr. Kamal Chaouachi's comments on our study published previously in the Environmental Science and Pollution Research journal (Chaouachi 2013; Khlifi et al. 2013). First, we wish to thank him for his interest in our work and the time he took to carefully analyse some complex details, particularly in relation to tobacco smoking in Tunisia.

No doubt that his comments show that he is an international expert in this field and for this reason also we apologise for our misquotation of his work in our study. We confirm that the right reference about shisha smoking and oral cancer was the important article he published with his colleague Dr. Sajid in the Medical Hypotheses journal (Chaouachi and Sajid 2010).

On another level, we also appreciated very much his proposals to enhance the methodology of our future studies and in particular the issue of the questionnaire. After enquiry here in Tunisia, we can say that he is quite right about the need to distinguish between different smoking products (jurak, tobamel, etc.) and the different ways to prepare them (with aluminium or not, etc.) in order to avoid confusion by excessive simplification. Finally, the pioneering studies about heavy metals (Saudi Arabia and Egypt) that we did not know, unfortunately, and in which he was involved, deserve in our view great attention (Khater et al. 2010).

\section{References}

Chaouachi K (2013) Shisha smoking, nickel and chromium levels in Tunisia. Environ Sci Pollut Res Int. doi:10.1007/s11356-0131935-z

Chaouachi K, Sajid KM (2010) A critique of recent hypotheses on oral (and lung) cancer induced by water pipe (hookah, shisha, narghile) tobacco smoking. Med Hypotheses 74:843-6. doi:10.1016/j. mehy.2009.11.036

Khater AE, Amr M, Chaouachi K (2010) Uranium and heavy metals in narghile (shisha, hookah) moassel. Session on environmental radioactivity. Poster 11-P-18. The Third Asian and Oceanic Congress on Radiation Protection. IRPA (International Radiation Protection Association). Tokyo (Japan), 25 May. http://www.aocrp-3. org $/ \mathrm{p}$ _environ.html

Khlifi R, Olmedo P, Gil F, Feki-Tounsi M, Chakroun A, Rebai A, Hamza-Chaffai A (2013) Blood nickel and chromium levels in association with smoking and occupational exposure among head and neck cancer patients in Tunisia. Environ Sci Pollut Res Int. doi:10.1007/s11356-013-1466-7
Responsible editor: Philippe Garrigues

\section{R. Khlifi $(\varangle)$}

Unit of Marine and Environmental Toxicology, UR 09-03, Sfax

University, IPEIS, BP 1172, 3018 Sfax, Tunisia

e-mail: rimkhlifi@yahoo.fr 